\title{
'Condemned by some, read by all': the attempt to suppress the publications of the Louvain humanist Erycius Puteanus in 1608*
}

\author{
DEMMY Verbeke
}

On 19 March 1608, Erycius Puteanus, professor of Latin language and eloquence at the University of Louvain, confessed to his friend Maximilianus Plouverius (1566-1639) that he feared for his own life now that the Antwerp assembly had burned copies of his most recent work De conviviorum luxu epistola (Letter on the sumptuousness of banquets) ${ }^{1}$ : 'I hear, and it is not an untrustworthy rumour, that some copies have been burned in the Antwerp assembly; and they are only a small step away from directing a similar fury against the author'. ${ }^{2}$

Although we have only Puteanus' word on this auto da fé, and although the fear that a similar fate awaited his own person seems to be exaggerated, it is nonetheless certain that the publication of the Epistola was highly controversial and resulted in an official complaint against the author as well as his printer Gerardus Rivius $(\uparrow 1634) .^{3}$ One would naturally assume that readers objected to the Epistola on political or religious grounds, when one considers the numerous examples of other attempts to suppress a publication in the same period and/or place - for example, the zeal of the Duke of Alva, governor of the Spanish Netherlands from 1563 to 1573, to destroy all books on the expanded Tridentine Index, and the simultaneous burning of an author and his books as in the cases of Giordano Bruno (1600) and

\footnotetext{
* I would like to thank Ingrid De Smet and Adam Beaver, whose comments on earlier versions of this essay considerably helped to shape its final form. A Francqui Foundation Fellowship, granted by the Belgian American Educational Foundation, made the writing of this article possible.

${ }^{1}$ Eryci Puteani De conviviorum luxu Epistola. Ad clariss[imum] virum Ioannem Hollantium (Loveni [sic; Louvain]: Gerardus Rivius, 1608). Only a handful of copies of the Epistola - three according to the Bibliotheca Belgica. Bibliographie générale des Pays-Bas, IV (Brussels: Editions Culture et Civilisation, 1964), 766 - are preserved. I have used the copy of the Erfgoedbibliotheek Hendrik Conscience in Antwerp (siglum D2475).

${ }^{2}$ Koninklijke Bibliotheek van België, Brussels, MS 6523, fol. 9 (transcription provided by Michiel Verweij, Handschriftenkabinet): 'In curia Antverpiensi (ita audio, nec incerto rumore) exemplaria quaedam exusta sunt; et hoc defuit tantum, quod in auctorem pari furore non saevierint.'

${ }^{3}$ Diane Van Daele, Gerardus Rivius, drukker te Leuven E pedel van de theologische faculteit (1597-1634) (Lic. diss. Katholieke Universiteit Leuven, 1987) and Pierre Delsaerdt, Suam quisque bibliothecam: boekhandel en particulier boekenbezit aan de oude Leuvense universiteit, 16de-18de eeuw, Symbolae Facultatis litterarum Lovaniensis. Series A-27 (Louvain: Universitaire Pers Leuven, 2001), 403-04.
} 
Marcantonio de Dominis (1624). Indeed, scholarship on book-burning and other forms of censorship in the Catholic Netherlands of the early seventeenth century focuses on action taken by the inquisition in collaboration with the government against publications which were considered to be subversive for church and state alike. ${ }^{4}$

And yet, an examination of the case against Erycius Puteanus (1574-1646) will show that, in this case, the flames of censorship were primarily fuelled by moral concerns, petty jealousies and personal feuds. The analysis of his subsequent publication Comus sive Phagesiposia Cimmeria. Somnium (Comus, or the Cimmerian binge. A dream-story $)^{5}$ - the most enduring of all of Puteanus' works, and the only one which received not one, but two translations in the twentieth century ${ }^{6}$ - will furthermore explain how the author was able to publish a very similar work, about the same topic, in the very same year. Finally, the discussion of the immediate and ongoing success of the Comus - particularly noteworthy in seventeenth-century England - will demonstrate how Puteanus' adversaries achieved exactly the opposite of what they intended with their attempts to suppress his publications.

When the Louvain professor Justus Lipsius (b. 1547) died on 23 March 1606, the university was faced with the impossible task of finding a successor of similar stature. For several decades, the famous humanist - characterized by Anthony Grafton as 'one of the most puzzling and unnerving intellectual celebrities' of his time, who 'ranked with the most learned and creative members of his generation, ${ }^{7}$ - had dominated the republic of letters. Lipsius had offered ground-breaking contributions to the fields of classical scholarship (with his editions of Tacitus, 1574, and Seneca, 1605) and philosophy (De Constantia, 1584); and had taken part in the political, military and religious debates of his time (for example, with his highly influential Politicorum sive Civilis Doctrinae Libri Sex, 1589). Furthermore, he was considered to be a champion of the Counter-Reformation after his return to the Catholic South in 1591, resigning the chair at the Protestant University of Leiden which had been his for thirteen years. ${ }^{8}$

\footnotetext{
${ }^{4}$ Cf. Hermann Rafetseder, Bücherverbrennungen. Die öffentliche Hinrichtung von Schriften im historischen Wandel, Kulturstudien. Bibliothek der Kulturgeschichte Band 12 (Vienna, Cologne and Graz: Böhlau, 1988) and Haig Bosmajian, Burning Books (Jefferson, NC, and London: McFarland \& Co, 2006).

${ }^{5}$ Eryci Puteani Comus, sive Phagesiposia Cimmeria. Somnium (Lovanii: Gerardus Rivius, 1608).

${ }^{6}$ C. Sobry, 'Comus ou la Ripaille Cimmérienne d'Erycius Puteanus', Latomus, 1 (1937), 113-40 and 211-29; C. Sobry, Comus of de Kimmerische zwelgpartij (Antwerp: De Sikkel, 1938).

7 Anthony Grafton, 'Portrait of Justus Lipsius', The American Scholar, 56 (1987), 382-90, here 382.

${ }^{8}$ Numerous publications highlighting the international importance of Lipsius have appeared in the past two decades. The most noteworthy are Marc Laureys (ed.), The world of Justus Lipsius, a contribution towards his intellectual biography: Proceedings of a colloquium held under the auspices of the Belgian Historical Institute in Rome, Rome, 22-24 May 1997, Bulletin de l'Institut historique belge de Rome 68 (Turnhout: Brepols, 1998) and Gilbert
} 
In the end, the vacant position was offered to Erycius Puteanus, a former student of the deceased professor, who after his education in Dordrecht, Cologne and Louvain had left for Italy in 1597 at the instigation of Lipsius himself. ${ }^{9}$ Puteanus had spent the next nine years in close and friendly contact with the learned men of Italy, especially Cardinal Federico Borromeo (15641631) of Milan. ${ }^{10}$ He was appointed professor of Latin at the Palatine School in the same city in 1600. During these years, he published extensively, including a collection of letters - always a sign of the desire of the humanist in question to play a role of importance in the respublica litterarum.

Puteanus accepted the chair, but not everybody was happy with the chosen candidate. Many admirers of Lipsius complained that Puteanus was too young and too unworthy a scholar to succeed the great humanist. Balthasar Moretus I (1574-1641), for example, scolded that Puteanus was only appointed for lack of a better candidate. ${ }^{11}$ In a letter to Franciscus Raphelengius II (1568-1643), another former student of Lipsius, Moretus even exclaimed: 'We would prefer a Baudius, a Heinsius, or a Grotius over any Puteanus.' ${ }^{12}$

Puteanus was aware that the eyes of the European intelligentsia were fixed on him when he started teaching in Louvain in 1607. The Belgian critic Sobry argued that this awareness incited Puteanus to establish himself as a moral authority, whilst Puteanus' biographer Simar suggested that the professor wanted to develop, like his predecessor, a philosophy based on moral prescriptions. ${ }^{13}$ Out of this urge to give moral guidance, Puteanus wrote a letter to Johannes Hollantius (dated 4 November 1607) in which he criticized

Tournoy, Jeanine De Landtsheer and Jan Papy (eds.), Iustus Lipsius Europae lumen et columen: Proceedings of the International Colloquium, Leuven, 17-19 September, 1997, Supplementa Humanistica 15 (Louvain: Leuven University Press, 1999).

${ }^{9}$ For the biography of Puteanus, see Th. Simar, Étude sur Erycius Puteanus (1574-1646) considéré spécialement dans l'histoire de la philologie belge et dans son enseignement à l'université de Louvain, Université de Louvain. Recueil de travaux publiés par les membres des conférences d'histoire et de philologie, 23 (Louvain-Paris-Bruxelles: Université Bureau du Recueil, 1909) and Alphonse Roersch, 'Puteanus (Erycius) ou Eeryk de Putte', in Biographie Nationale, 18 (Brussels: Académie royale des Sciences, des Lettres et des Beaux-Arts de Belgique, 1905), col. 329-44.

${ }^{10}$ For the connection between Borromeo and Puteanus, see Dirk Sacré, 'A Forgotten Somnium: Philippus Wannemakerus (1586-1630) and his Triumphus Litteratorum, 1611', Lias, 31 (2004), 141-64, here 157-8 and Antonio Iurilli, 'Erycius Puteanus: dalla Biblioteca Ambrosiana alla Lovaniense', Accademie e bibliothece d'Italia, 65-3 (1997), 5-22.

${ }^{11}$ For Balthasar Moretus I, the grandson of Christophe Plantin who was briefly Lipsius' student and secretary in 1592/93, see Jeanine De Landtsheer, 'Balthasar Moretus's Sojourn in Louvain', in Ex officina Plantiniana Moretorum. Studies over het drukkersgeslacht Moretus [= De Gulden Passer 74] (Antwerp: Antwerpsche Bibliophielen, 1996), ed. Marcus de Schepper and Francine de Nave, 110-29 and Dirk Sacré, 'Balthasar I Moretus en Justus Lipsius', in Justus Lipsius (1547-1606) en het Plantijnse Huis, Publicaties van het Museum Plantin-Moretus en het Stedelijk Prentenkabinet 37 (Antwerp: Museum Plantin-Moretus, 1997), 109-28.

12 'Baudios, Heinsios, Grotios prae quovis Puteano amemus', quoted in Dirk Imhof, 'The Works of Erycius Puteanus Published by the Officina Plantiniana in Antwerp', Humanistica Lovaniensia, 49 (2000), 267-77, here 269. Moretus refers to Dominicus Baudius (1561-1613), Daniel Heinsius (1580-1655), and Hugo Grotius (1583-1645). Sacré, 'Balthasar I Moretus en Justus Lipsius', 116-17, offers further proof of Moretus' negative attitude towards Puteanus.

${ }^{13}$ C. Sobry, 'Comus ou la Ripaille Cimmérienne d'Erycius Puteanus', 114; C. Sobry, Comus of de Kimmerische zwelgpartij, $\mathrm{x}$ and Simar, Étude sur Erycius Puteanus, 40. 
gluttony and drunkenness. He subsequently published this letter-pamphlet at the beginning of 1608 under the title De conviviorum luxu epistola.

In order better to understand the motives of the author, and reconstruct the circumstances in which the Epistola was written, we turn to the so-called paratexts: all texts which can be connected with the production, publication and presentation of the book. ${ }^{14}$ Several studies have shown that the analysis of this paratextual material can provide invaluable information about the intentions of the author and the mediation and reception of his work. ${ }^{15}$ In his preface addressed to the anonymous reader, Puteanus explained why he had chosen to publish the letter. Apparently, some (unidentified) individuals had criticized him for praising the amoenitas (cheerfulness) of Louvain's students and other youngsters too much in his oration Iuventutis Belgicae Laudatio (Eulogy on the youth of the Low Countries), published in 1607. According to the author, people were now wondering whether he meant to praise the hilarity elicited by the use of alcohol, and he therefore felt the need to take a firm stand against drunkenness:

If I hate and despise one moral lapse, it is certainly drunkenness; and I almost hate and despise (if you will permit me to say this) the men who feed this drunkenness with their most stupid sense for pleasure.... It was not that drunkenness, but gaiety, which I celebrated with my humorous eulogy. ${ }^{16}$

Despite these good intentions, the publication of Puteanus' Epistola caused immediate commotion. Some citizens of Antwerp, a city known for its love of sumptuous banquets, felt personally attacked and demanded legal action against the author as well as against the printer. The precise details are lacking, but it seems that the complaint resulted in an official inquiry by the authorities, a fine for Puteanus, ${ }^{17}$ and a subsequent appeal by the Antwerp plaintiffs to Petrus Pecquius (1562-1625), ${ }^{18}$ chancellor and member of the Grand Council in Mechlin, one of the highest court houses in the Habsburg

\footnotetext{
${ }^{14}$ See Gérard Genette, Seuils, Collection Poétique (Paris, 1987), 7-11, for the definition and classification of paratexts.

${ }^{15}$ See, for instance, Arnaud Tripet, Montaigne et l'art du prologue au XVIe siècle, Études montaignistes IX (Paris: Libr. H. Champion, 1992) and Guyda Armstrong, 'Paratexts and their Functions in Seventeenth-Century English Decamerons', Modern Language Review, 102 (2007), 40-57.

${ }^{16}$ Quoted from the message to the reader in Epistola, 3-6: '. . . si ullam morum labem, hanc [ebrietatem] potissimum odi et exsecror, et paene homines (liceat dicere) qui stultissima eamdem voluptate alunt ... Sed non Ebrietas illa, Hilaritas fuit; quam et ego ridente elogio celebravi.'

${ }^{17}$ See Puteanus' letter to Plouverius again, mentioned in footnote 1: 'Dum haec scribo, venit ad me typographus, et molestiarum nuncium defert: hodie adfuturum Procuratorem Generalem, ut mulctam prosequatur' (While I am writing this, the printer comes to me and brings me bad news: the general procurator will be present today to pursue a fine).

18 Cf. Simar, Étude sur Erycius Puteanus, 8; Sobry, 'Comus ou la Ripaille Cimmérienne d'Erycius Puteanus', 114 and Sobry, Comus of de Kimmerische zwelgpartij, x. Apparently, Petrus Pecquius was on a diplomatic mission at the French court of Henri IV from 1607 until 1610 (cf. V. Brants, 'Peck (Pierre)', in Biographie Nationale, 7 (Brussels: Académie royale des Sciences, des Lettres et des Beaux-Arts de Belgique, 1901), col. 784-92, here col. 785), so the appeal must have reached him there.
} 
Netherlands. ${ }^{19}$ Another indictment, written by Laurentius Beyerlinck (15781622), the Antwerp censor librorum, canon of the cathedral and president of the seminary in the same city, was sent to the city magistracy of Louvain.

In an effort to defend himself, the Louvain professor decided to write to the city magistracy of Antwerp and to Nicolaas Damant (1531-1616), a prominent member of the Privy Council, the Council of State and - most importantly also the Chancellor of Brabant (being the president of the States of Brabant). Both letters tendered a mixture of apologies and defence; and each time the same argument featured prominently: the author wanted to attack the sin of gluttony, but had absolutely no intention to offend a particular city or individuals:

To the reverend man Nicolaas Damant, Chancellor of Brabant. . . I have written about sumptuousness; and that is considered to be my first crime; afterwards I have published, and that would be my second crime. It was my intention to reproach the common and plebeian vices of a few and to stress sobriety and moderation; and that was the purpose of that famous Epistola. Alas! Will it be a crime to speak about virtue? . . Good God, what world is this in which we live and write? Will one not be allowed to show disgust of vices? What is left then, but to silence the preachers, to close the schools, to ban wisdom? ${ }^{20}$

\section{The tone is very similar to that of the Antwerp letter:}

To the city magistracy of Antwerp. Noble, distinguished and wise men. The ancient authors tell us that the waves of the sea are quieted when you pour oil on them; and with oil, they mean mildness. This mildness is yours and I make an appeal to it so

\footnotetext{
19 During the reign of the Archdukes Albert and Isabella (1598-1621), political and legal power was divided between the archdukes, three assisting councils (the Council of State, the Council of Finance, and the Privy Council), the Provincial States, and - in large towns - the city magistrates. The Grand Council of Mechlin mostly acted as a court of appeal. Local authorities or individuals could bring a matter to the government's attention by sending a so-called 'Request'. A member of the appropriate council (usually the Privy Council) was then entrusted with the investigation of the matter and sought information from the Provincial States, local authorities and/or the individuals involved. The resulting report was presented to the Privy Council, which made a recommendation to the archdukes. The procedure allowed a lot of influence from court dignitaries. See Charles H. Carter, 'Belgian "Autonomy” under the Archdukes 1598-1621', Journal of Modern History, 36 (1964), 245-59; Hugo de Schepper and Geoffrey Parker, 'The Formation of Government Policy in the Catholic Netherlands under the Archdukes 1596-1621', English Historical Review, 91 (1976), 241-54; Hugo de Schepper, 'Les archiducs et les institutions du gouvernement au Pays-Bas espagnol, 1596-1621', in Albert E $\mathcal{F}^{\text {Isabella }}$ 1598-1621. Essays edited by Werner Thomas and Luc Duerloo (Brussels: Brepols Publishers, 1998), 221-32 and Karin Van Honacker, 'The Archdukes and Their Subjects: The Political Structure of the Citizens in the Netherlands', in Albert $\mathcal{F}^{2}$ Isabella 1598-1621, 241-47. I wish to thank Violet Soen for sharing her vast knowledge of the administrative structure of the Habsburg Netherlands.

${ }^{20}$ Letter of 16 March 1608, quoted from Eryci Puteani Epistolarum Atticarum missus secundi, in centurias tres divisi: iam vero centuria singulari et nova aucti (Coloniae [Cologne]: Simon Paullus, 1663), I: lviii: 'Nicolao Damantio $V$ [iro] A[mplissimo], Brabantiae Cancellario.... De luxu scripsi, et hoc primum velut crimen notatur; deinde edidi, et hoc secundum. . . Mens mea fuit, communia aut plebeia paucorum vitia reprehendere, sobrietatem modestiamque inculcare; et in hanc metam tota illa Epistola directa. Hem! Crimen erit, pro virtute loqui? . . O bone Deus, quo seculo vivimus, quo scribimus! Itane odium vitiorum profiteri non licebit? Quid reliquum est, nisi ut sacra quoque pulpita sileant, ut scholae claudantur, ut sapientia exulet?'
} 
that peace and tranquillity return. ... I swear to God, it was not my goal, nor my intention to offend your city... This letter on sumptuousness is written not to irritate, but to correct the minds of the Belgians. And so I want you to indicate, not to punish, what gives offence. Once corrected, it will please you. ${ }^{21}$

Puteanus was clearly surprised and upset by the upheaval caused by his Epistola and tried to effect reconciliation. The controversy probably even made him consider decamping to the University of Bologna, which had offered him a chair in Latin, but he was eventually persuaded to stay in Louvain, perhaps by an appointment as royal historiographer and other favours bestowed upon him by the archdukes. ${ }^{22}$

On the other hand, the professor never admitted any guilt in the affair. He unequivocally defended himself against what he believed to be a deliberately false and mischievous interpretation of his moral stance. Although Puteanus did not express this in his aforementioned letters, he did have a clear idea of who was behind the attacks on his person. In particular, he identified as the instigators Johannes Woverius (†1635 or 1636), another former student of Lipsius (and executor of his will) and now member of the Antwerp magistracy, and the already mentioned Laurentius Beyerlinck. He did not hide his contempt for these men, producing insulting epigrams directed against Woverius $^{23}$ and stating:

That despicable man Beyerlinck has written to the people of Louvain and has stuffed his letter with so many dirty insults, worthy of a pimp, that it seems that the letter came from a brothel instead of from a seminary. I laugh with these scoffs, because I do not deem that pest of a man worthy of my anger. ${ }^{24}$

It is indeed clear that admirers of Lipsius, such as Moretus, Beyerlinck and Woverius, continued to criticize Puteanus for being an unworthy successor; and that this Antwerp circle of humanists undoubtedly played an important role in the uproar following the publication of the Epistola. They may even

${ }^{21}$ Letter of 22 March 1608, quoted from Eryci Puteani Epistolarum Atticarum promulsis, in centurias tres distributa (Coloniae [Cologne]: Ludovicus Elzevirus, 1616), III: lxiv: 'Consulibus et Senatui Antverpiensi. Viri nobiles, magnifici, prudentes. Maris fluctus infuso oleo sedari veteres tradunt: per oleum autem, Lenitatem significarunt. Haec vestra est; et ad hanc venio ut quies redeat et tranquillitatis aura. . . . Nec mens, nec voluntas mea fuit (Deum testor) Urbem vestram laedere ... Non enim irritandis, sed corrigendis Belgarum animis, haec de luxu scripta. Itaque ut indicetis, non vindicetis, quae displicent, cupio: placebunt emendata.'

22 This suggestion in Simar, Étude sur Erycius Puteanus, 10-11.

23 These epigrams are quoted in Simar, Étude sur Erycius Puteanus, 9. Aubertus Miraeus nonetheless indicated in his biography of Justus Lipsius, published in 1609, that Woverius (initially) supported Puteanus: 'Amici Oudartus, Corselius, Woverius, Iohannes Baptista Perezius et ego, qui funeribus interfueramus, Erycium Puteanum ... prae ceteris laudabamus' (The friends Oudartus, Corselius, Woverius, Johannes Baptista Perzius and myself, who were at [Lipsius'] funeral, praised Erycius Puteanus above all others - quoted in Karl Enenkel, 'Lipsius als Modellgelehrter: Die Lipsius-Biographie des Miraeus', in Iustus Lipsius Europae lumen et columen, 47-66, here 50.

${ }^{24}$ Quoted from the letter to Plouverius d.d. 19 March 1608 (see n. 1): 'Ita Beyerlinck iste ad Lovanienses scripsit, tamque impuris et Lenone dignis conviciis epistolam implevit, ut non e seminario, sed e lupanari profecta videatur. Ego rideo haec scommata, nec ira mea dignum tumorem istum hominis habeo.' 
have orchestrated the whole riot to undermine Puteanus' position, conducting a smear campaign against the newly appointed professor. ${ }^{25}$ Puteanus was nonetheless able to successfully defend himself and refused to be silenced by what he considered to be the evil machinations of the envious Antwerp humanists. Still wanting to have the last word on the matter of gluttony, he published a second work on the same topic later that year, calling it Comus, sive Phagesiposia Cimmeria. Somnium, which is - as research by Dirk Sacré has brought to light - a thoroughly reworked and expanded version of the Epistola. Puteanus explained his motives in a letter to Cornelius Marcanus dated 1 July 1608:

It proved almost unfortunate for me to speak about sumptuousness. But that is life. Now I publish the Comus sive Phagesiposia. It is a dream, and at least I dare to philosophize with a jest. Because it is forbidden to do this in our world, I pursue the sumptuousness of banquets with the Cimmerians, that is, with people who don't exist. ${ }^{26}$

In other words: the author wished to make the same point as he did in his Epistola, but was aware that he had to be careful not to stir emotions again. He therefore decided to present his moral lesson in a different way. Whereas the Epistola was a public letter, a pamphlet with a very direct statement from Puteanus to his readers, the Comus would be a dream-story. This choice of genre is of course a defensive strategy (as Ingrid De Smet has already shown): Puteanus anticipated criticism by representing the Comus as a work of fiction. ${ }^{27}$ He says as much by adding Somnium on the title page, and by making this statement in the very first paragraph of the Comus:

I will tell things that did not happen and will not happen. . . . It is a dream-story, and I should be allowed to tell this; and to correct the reader who wants this to be the description of something that happened or will happen. Go away, and find your money, the price for your lies, elsewhere..$^{28}$

\footnotetext{
${ }^{25}$ Sacré, 'A Forgotten Somnium: Philippus Wannemakerus (1586-1630) and his Triumphus Litteratorum, 1611', 159.

${ }^{26}$ Quoted from Epistolarum Atticarum promulsis, III: lvii: 'Mihi de luxu loqui, infaustum paene fuit. Sic vivitur. Comum sive Phagesiposia nunc edo. Somnium est, et per ludum saltem audeo Philosophari. Quia in orbe nostro non licet, apud Cimmerios, id est, apud eos qui nusquam sunt, luxum convivalem persequor.'

27 Cf. Ingrid De Smet, Menippean Satire and the Republic of Letters 1581-1655, Travaux du Grand Siècle II (Geneva, 1996), 110-11. See also Simar, Étude sur Erycius Puteanus, 64.

28 'Quae nec facta, nec futura [sunt], dicam . . . SOMNIUM est, et hoc narrare mihi liceat; sed interpretem arcere, qui aut facta, aut futura volet designari. Abi, et dragmam alibi pete, mendacio praemium.' This and all following quotations from the Comus are based on the copy of the first edition preserved in the Erfgoedbibliotheek Hendrik Conscience, Antwerp (siglum C2068). I compared this edition with the revised editions Eryci Puteani Comus, sive Phagesiposia Cimmeria. Somnium: secundo jam et accuratius editum (Lovanii: Gerardus Rivius, 1610; copy: Universiteitsbibliotheek Leuven, Louvain, BTAB Caa A92) and Eryci Puteani Comus, sive Phagesiposia Cimmeria. Somnium. Secundo jam et accuratius editum (Lovanii: Gerardus Rivius, 1611; copy: Erfgoedbibliotheek Hendrik Conscience, Antwerp, C2069). The brackets indicate the additions appearing in the 1610/11 editions, which are identical except for the title-page.
} 
Puteanus not only countered criticism by using the genre of the dream-story but also prepared the ground for the publication of his Comus with the aforementioned conciliatory letters to the City Council of Antwerp and the Chancellor of Brabant. Moreover, he turned to powerful allies to protect his new publication, and exhibited this alliance through a clever use of the traditional preliminaries which were placed before and after the central text, thus shielding it from all sides.

The dedication of the Comus is addressed to Christoph Van Etten, a jurist and, like him, a former student of Lipsius, but more importantly, also the son of Hendrik Van Etten, president of the Audit of Brabant since 1597. ${ }^{29}$ The help of the elder Van Etten had been crucial in the suppression of the complaint against Puteanus and Rivius. ${ }^{30}$ The Louvain professor subtly referred to this protection in his dedication letter of the Comus and explicitly solicited the same safe-keeping from the dedicatee and his father for this new publication:

You will accept this small gift, of which your father already had a little taste. You will accept it, because I seem to be giving to your father what I give to you. What I owed him as requital for my good name and tranquility, I give to you; and - as if it was not enough to protect my Comus with the authority of one person - I prefix it with the authority of two. He who offends this book, will offend your name and your father's; and your father will protect this book when he sees that it is yours. You will protect it too and will control the furious insanity and clattering of unlearned spite. ${ }^{31}$

The text of the satire is followed by an authorial address to the anonymous reader in which Puteanus explains that he felt forced to defend himself against slander and introduced the following defensive paratext:

To the fair reader. I have told a dream ... But now, because they force me to do this, they will find an obstacle against that impure and poisonous talk that is hostile towards my name, my fame and my peace through mere spite. This obstacle, I say, is this letter which was sent by the senate of Milan to the States of Brabant . . . Dear reader, look at this letter and fare well. ${ }^{32}$

\footnotetext{
${ }^{29}$ See the recommendation letter, written by Lipsius for his student, as well as a letter by Van Etten jr. to his teacher, dated 10 July 1600, published in Iusti Lipsi Epistolae. Pars XIII: 1600, ed. Jan Papy (Brussels, 2000). The Audit of Brabant was an important administrative institution on the provincial level, with certain judicial powers (cf. Erik Aerts, 'Rekenkamer van Brabant (1404-1735)', in De centrale overheidsinstellingen van de Habsburgse Nederlanden, ed. Erik Aerts et al., Algemeen Rijsarchief en Rijksarchief in de Provinciën. Studia 55 (Brussels: Algemeen Rijksarchief en Rijksarchief in de Provinciën, 1994), 2 vols., II, 622-32.

${ }^{30}$ Simar, Étude sur Erycius Puteanus, 9.

31 'Accipies igitur munusculum istud, quod iam prior pater libavit: accipies, quod dare patri videor, quia tibi. Illi debebam famae et tranquillitatis hostimentum, tibi solvo. Et quasi parum esset unius auctoritate Comum meum munire, geminam praescribo. Tuum patrisque laedet nomen, qui hunc librum; et quem tuum videbit pater, defendet. Tu defendes quoque et furentem indocti livoris insaniam strepitumque compesces.'

32 'Candido lectori. Somnium narravi ... Sed nunc, quia huc me cogunt, obstaculum impurae illae et vipereae linguae inveniant: illae nomini, famae, et tranquillitati meae per merum Livorem infestae. Obstaculum, inquam, hanc epistolam, a senatu Mediolanensi ad ordines Brabantiae missam . . Tu vide, lector, et salve.'
} 
The message to the reader is indeed followed by a letter, written by Giambattista Sacco, president of the senate of Milan, a patron and close friend of Puteanus, ${ }^{33}$ and addressed to the States of Brabant. This letter was originally written in October 1606 in connection with Puteanus' appointment at the University of Louvain. The professor decided to print it in his Comus, undoubtedly with the writer's consent, so that it could serve as a public and indisputable testimony to his probity and learning. Sacco described Puteanus' career in Italy and praised his many merits to the state of Milan, his erudition and his virtuous lifestyle. In this way, the letter confirmed the message that Puteanus wanted to convey, namely that he was neither the unworthy successor the Antwerp humanists made him out to be, nor the trouble-maker he may have seemed to be in light of the controversy aroused by his Epistola.

A fourth and last paratext, relevant for the strategic presentation of the Comus, is the imprimatur signed by the Louvain censor Guilielmus Fabricius (c. 1553-1628), the same person who had granted permission to publish the Epistola. ${ }^{34}$ Interestingly, Fabricius did not take recourse to a bland, traditional formula, to say that nothing prevented the publication of the book, but explicitly stated that nobody should be offended by this story and had the important elements in this statement printed in italics:

Approbation. I consider this dream-story, entitled Comus sive Phagesiposia Cimmeria, written by Erycius Puteanus, professor of Latin language and eloquence at the University of Louvain, worthy of publication because it mocks the common morals of our world and the sumptuousness of our age, and primarily the sumptuousness of banquets, to no blemish of any group of people or city; and I judge that it can be read to the advantage and pleasure of the public. $^{35}$

Puteanus continued to pay attention to the strategic use of preliminary texts in reprints of the Comus: he not only included his dedication to Van Etten, the address to the reader, and Sacco's letter of recommendation, but also added poems by Daniel Heinsius, Cornelius Lummenaeus a Marca and Nicolaus Burgundius $^{36}$ to the authorized reprints of 1610 and 1611. His correspon-

${ }^{33}$ Simar, Étude sur Erycius Puteanus, passim and Sacré, 'A Forgotten Somnium: Philippus Wannemakerus (1586-1630) and his Triumphus Litteratorum, 1611',144.

${ }^{34}$ Fabricius' imprimatur for the Epistola (dated 28 January 1608) read: 'Haec Epistola, quod et tempori congruat, et a convivialis luxus foeditate absterreat, digna est quae in lucem exeat' (This Epistola is worthy to be printed, because it convenes with the times and drives the foulness of sumptuousness at banquets away).

35 'Approbatio. Somnium hoc, titulum Comi, sive Phagesiposiorum Cimmeriorum praeferens, ab Erycio Puteano, linguae et eloquentiae Latinae in Academia Lovaniensi Professore publico scriptum; quia in promiscuos orbis mores, et aevi nostri luxum, praesertim convivalem, nullius Gentis aut Urbis dehonestamento ludit, dignum censeo quod in lucem exeat, cum fructu et voluptate publica legendum.' The italics are thus printed in the original editions from 1608,1610 and 1611.

${ }^{36}$ Nicolaus Burgundius (1586-1649), a former student of Puteanus, broke with his teacher later in life, siding with another former student, Frederik de Marselaere (1584-1670), in the dispute over Marselaere's Legatus (published in Antwerp in 1626). See F. Steyaert, 'Puteanus Criticized by a Former Student, Nicolaus Burgundius', Lias, 3 (1976), 131-8. 
dence proves that it was Puteanus himself who invited these poetic tributes, ${ }^{37}$ thus making clear to the public that he had the support of other members of the republic of letters.

This well-planned, strategic presentation of the Comus seems to have borne fruit. Whilst the Comus still inspired some controversy, there is no indication that it was as strong as the commotion caused by the earlier Epistola. Indeed, the dispute with the city magistracy of Antwerp seems to have settled down; and Balthasar Moretus (who later printed some of Puteanus' works), Laurentius Beyerlinck (who provided the imprimatur for Puteanus' books published in Antwerp) and Johannes Woverius (who reconciled himself with Puteanus in 1611) seem to have abandoned their opposition, although there was undoubtedly little friendship lost between the parties. ${ }^{38}$

A few years later, Puteanus even showed himself resigned to being vilified. In a letter from 1611, he indicated that 'No-one has ever criticized the morals of a festered time, without encountering enemies. ${ }^{39}$ Furthermore, the Louvain professor realized very well that the original, negative response to the Epistola had resulted in a true succès de scandale for the Epistola and the Comus alike. Puteanus admitted as much in a letter to Arnoldus Baert (15541629), member of the Grand Council in Mechlin:

I have searched for the Epistola de luxu, but in vain. I think that Ceres would sooner find her daughter than I would find the Epistola.... What certain people desired, indeed happened: this little book has fled from the eyes and hands of the Belgians. Better still: what they did not want, happened: it is sold, so that it could not perish. Condemned by some, so that it would be read by everyone. And why? Because some people disliked it, it started to please better people. ${ }^{40}$

So successful and notorious was the Epistola that it became hard to find a copy, all of which had sold out. For many years the Comus enjoyed a similar success. Reprints of the satire were published in Louvain, Strasbourg, Leiden and

\footnotetext{
37 See the letter of Puteanus (d.d. 24 November 1609) addressed to Lummenaeus a Marca, published in Epistolarum Atticarum missus secundi, II: 12: 'Novam Comi editionem paramus: an ludere quidpiam lubet? Heinsii, doctissimi sine comparatione hominis in omni genere Litterarum, Heinsii, inquam, Musa etiam in hoc limine conspicietur' (I am preparing a new edition of the Comus. Would you want to write a poem for this? The muse of Heinsius, that man most learned beyond comparison in all aspects of literature, will also be present among these preliminaries).

${ }^{38}$ See, respectively, Imhof, 'The Works of Erycius Puteanus Published by the Officina Plantiniana in Antwerp', pp. 276-7; Jozef IJsewijn, 'Beyerlinck, Laurentius', in Nationaal Biografisch Woordenboek, 12 (Brussels: Koninklijke Academiën van België, 1987), col. 59-67, here col. 66 and Simar, Étude sur Erycius Puteanus, 10.

${ }^{39}$ Letter of 28 November 1611, quoted from Epistolarum Atticarum missus secundi, II: 35: 'Mores nemo reprehendit exulcerati aevi, qui non hostes inveniret.'

${ }^{40}$ Letter of 14 November 1611, quoted from Epistolarum Atticarum missus secundi, II: xlviii: 'Epistolam de Luxu quaesivi, sed irrito conatu. Citius opinor, filiam suam Ceres, quam ego hanc invenero.... Quod fieri homines aliqui voluerunt, tandem contigit: oculos manusque Belgarum libellus iste fugit. Imo quod noluerunt, contigit: ne perire posset, divenditus est. A quibusdam damnatus, ut a omnibus legeretur. Quid etiam? Placere melioribus coepit, quia nonnullis displicuit.'
} 
Oxford in 1610, 1611, 1628, ${ }^{41} 1630{ }^{42}$ and $1634 .{ }^{43}$ The Comus also became one of the standard examples of satirical writing, anthologized in the Elegantiores praestantium virorum Satyrae, a compendium of prose satires published in Leiden in $1655 .{ }^{44}$ The satire was translated into Dutch as early as $1611,{ }^{45}$ with a French translation swiftly following suit in 1613. ${ }^{46}$ Another French and Dutch translation followed in 1937 and 1938. ${ }^{47}$

The reception in seventeenth-century England was more complicated. In 1634, a play written by John Milton (1608-1674), entitled Comus. A Maske Presented at Ludlow Castle, was first performed in celebration of the installation of John Egerton, Earl of Bridgewater, as President of Wales. The masque was printed anonymously in 1637, and later incorporated, by Milton himself, in his Poems (first published in 1645). Milton scholars are still debating the sources of his Comus, but it has been argued that it is 'extremely likely that Puteanus was the immediate source' of Milton. ${ }^{48}$ Another celebrated English author, Walter Charleton (1619-1707), member of the Royal Society and physician to Charles I and II, was likewise inspired by Puteanus' Comus. He translated a story taken from the satire into English and published it in 1668 under the title The Cimmerian Matron. ${ }^{49}$ Finally, in 1671, a complete English translation of the Comus appeared in London, entitled The Vision of Theodorus Verax. ${ }^{50}$ This version, signed by the unknown author Bryce Blair, was presented as an original work, but Charles Mish discovered in 1967 that it is in fact a fairly adequate translation of Puteanus' satire. ${ }^{51}$

It is impossible to determine how much the controversial nature of Puteanus' discussion of gluttony and drunkenness contributed to its reception in England or elsewhere in Europe. It was in any case instrumental that the author managed to prevent the suppression of his Epistola and was able to channel the controversy into success for his Comus. Although the fears for his

\footnotetext{
41 Eryci Puteani Comus, sive Phagesiposia Cimmeria. Somnium. Additi sunt eiusdem autoris, Thyrsi Philotesii, sive amor Laconissans $\mathcal{E}^{2}$ consolatio Caecitatis (Argentorati: heirs of Lazarus Zetznerus, 1628).

${ }^{42}$ Eryci Puteani Comus, sive Phagesiposia Cimmeria. Somnium (Lugduni Batavorum: Josephus Navius, 1630).

${ }^{43}$ Eryci Puteani Comus, sive Phagesiposia Cimmeria. Somnium (Oxonii: Gulielmus Turner, 1634).

${ }^{44}$ Elegantiores praestantiorum virorum Satyrae, quarum titulos et nomina auctorum versa pagella exhibebit post praefationem, 2 vols. (Lugduni Batavorum: Ioannes Maire, 1655).

45 Eryci Puteani Comus, Dat is Brasgodt ofte Slemp-Feeste der Cimmerianen, In ghedaente van eenen Droom. Uyt den Latyne in Neder-landtsche taele overgheset, door P.S. (Tot Loven: Philips van Dormael, 1611).

${ }^{46}$ Comus, ou Banquet dissolu des Cimmeriens. Songe. Où par une infinité de belles feintes, galyes, gentilles $\mathcal{E}{ }^{\circ}$ serieuses inventions, les mœurs dépravées de ce siecle (é principalement aux banquets) sont doctements, naivement, É singulierement décrites, reprises, Ė condamnées. Traduit du Latin d'Erycius Puteanus, conseiller des Serenissimes Archiducs, Professeur de leurs Altesse en l'Université de Louvain, Ė Historiographe du Roy Catholique. Par Nicolas Pelloquin (Paris: Nicholas La Caille, 1613).

${ }^{47}$ See footnote 6.

48 Ralph H. Singleton, 'Milton's Comus and the Comus of Erycius Puteanus', PMLA, 58 (1943), 949-57, here 957. See also Ross Leasure, 'Milton's Queer Choice: Comus at Castlehaven', Milton Quarterly, 36 (2002), 63-86, here 69-70.

49 This novel forms the second part of a publication entitled The Ephesian and Cimmerian Matrons: Two Notable Examples of the Power of Love E Wit ([London], 1668).

50 The Vision of Theodorus Verax. By Bryce Blair, Gentleman (London: William Leake, 1671).

${ }^{51}$ Charles C. Mish, 'Comus and Bryce Blair's Vision of Theodorus Verax', Milton Newsletter, 1 (1967), 39-40.
} 
own life, as expressed in his letter to Plouverius, were probably exagerrated, there was a real danger that he would be silenced by the authorities on suspicion of libel. Thanks to the support of ecclesiastical and political dignitaries, however, Puteanus was still able to publish his Comus, which showcased this support in its paratexts: Van Etten, the president of the Audit of Brabant, allowed his name to be attached to the publication; Sacco, an intellectual authority of international reputation, offered a flattering character reference; and Fabricius, censor for the church and the archdukes, made an extra effort in his imprimatur to state the acceptable - even desirable - contents of the publication. And thus, despite the antagonism of the Antwerp humanists, the Comus helped to build Puteanus' reputation, not only as 'the undisputed master of Latin authors in Belgium, ${ }^{52}$ but also as one of the most respected intellectuals in Europe..$^{53}$

Centre for the Study of the Renaissance, University of Warwick

52 Simar, Étude sur Erycius Puteanus, 192: 'le chef incontesté des littérateurs latins de Belgique.'

53 This importance is illustrated by his vast correspondence - an estimated 20.000 letters written by or to him - and the attraction he exerted on dozens of international students. Cf. Dirk Sacré (ed.), Acta Puteana. Proceedings of the International Colloquium Erycius Puteanus (1574-1646). Leuven-Antwerp, 7-9 November 1996, published as part of Humanistica Lovaniensia, XLIX (2000), esp. 169-70. 